\title{
Treatment of gonorrhoea with penicillin, cephaloridine, and doxycycline
}

\author{
J. SÖLTZ-SZÖTS AND E. KOKOSCHKA \\ II Vienna Hautklinik, Vienna, Austria
}

During the period from January, 1971, to May, 1972, gonorrhoea was diagnosed in 512 female patients who were treated at the Second Dermatological Clinic of the University of Vienna; 410 were prostitutes admitted to the hospital and 102 women received out-patient treatment.

Initial diagnosis was based on smears, but always confirmed by culture.

To minimize the number of therapeutic failures and elucidate their cause, the following routine procedures were also carried out:

(1) Determination of the penicillin sensitivity of the gonococcal strains.

(2) Determination by culture of other flora.

(3) In all out-patients, examination and if necessary treatment of their partners to prevent re-infections.

(4) Pelvic examination in order to judge the influence of any adnexal involvement on the success of the therapy.

\section{Therapy}

Four groups of these female patients were treated with four different schedules:

(1) 300 patients were given two intramuscular injections each of $2 \mathrm{~m}$.u. procaine penicillin $G$ at an interval of $24 \mathrm{hrs}$.

(2) 62 patients were given two intramuscular injections each of 3.6 m.u. sodium penicillin $G$ plus 400,000 i.u. procaine penicillin $G$, at an interval of $24 \mathrm{hrs}$.

(3) Fifty patients were given a single intramuscular injection of $2 \mathrm{~g}$. cephaloridine.

(4) 100 patients were given two oral doses of $300 \mathrm{mg}$. doxycycline with an interval of $8 \mathrm{hrs}$.
MALES

During the same period 421 men suffering from gonorrhoea without complications were treated with the first schedule.

\section{Findings}

All patients, both inpatients and outpatients, were examined at least once after treatment, and routine cultures were made.

The sensitivities of the strains of gonococci isolated ranged between 0.0039 and 2 i.u. penicillin per $\mathrm{ml}$. (Fig. 1). The strains cultured from the prostitutes were just as sensitive as those from the outpatients. In all strains the penicillin sensitivity was such that treatment consisting of two injections of 2 m.u. procaine penicillin $G$, administered at an interval of $24 \mathrm{hrs}$, ought to have been sufficient to effect a cure (Fig. 1, and Fig. 2, overleaf).

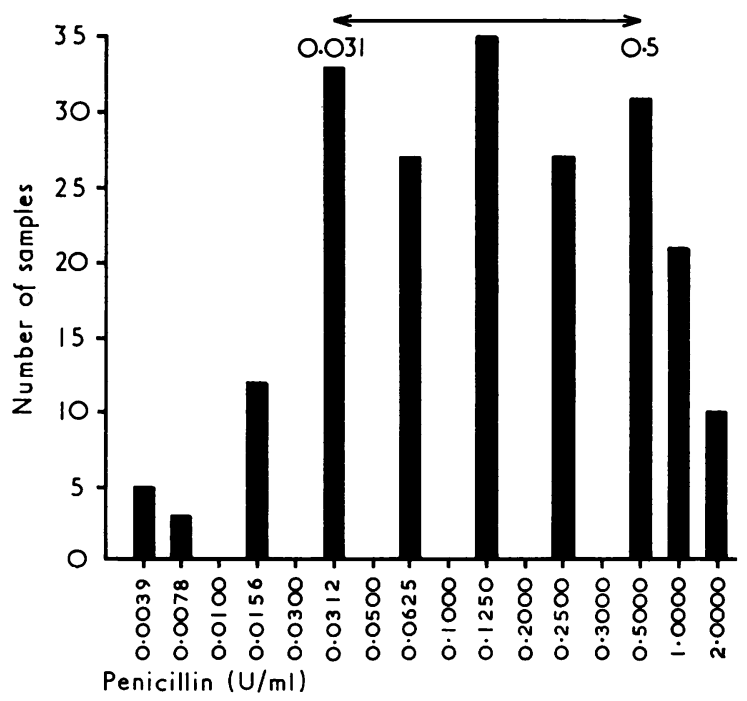

FIG. 1 Penicillin sensitivity of gonorrhoea in 1971 


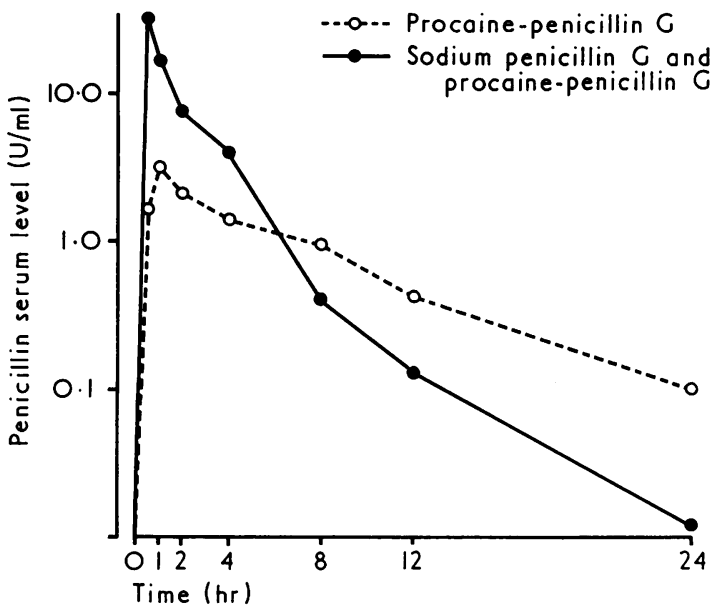

FIG. 2 Mean penicillin serum levels after injection of 2 m.u. procaine penicillin $G$ and of 3.6 m.u. sodium penicillin $G$ with $400,000 u$. procaine penicillin $G$

The following other organisms were isolated in culture:

\begin{tabular}{|c|c|c|}
\hline \multirow{2}{*}{ Organisms } & \multicolumn{2}{|c|}{ Persons examined } \\
\hline & No. & Per cent. \\
\hline Total & 512 & 100 \\
\hline Staphylococcus aureus & 395 & $77 \cdot 4$ \\
\hline B. coli & 168 & $33 \cdot 0$ \\
\hline Enterococci & 144 & $28 \cdot 2$ \\
\hline Diphtheroids & 103 & $20 \cdot 2$ \\
\hline B. proteus & 62 & $12 \cdot 0$ \\
\hline
\end{tabular}

In the cases of the 102 female outpatients included in this study, the male partner-whenever knownwas asked to attend for examination and was treated at once if found to be infected. These measures succeeded in reducing the number of re-infections but did not completely eliminate them.

In 74 women (14.65 per cent.), pelvic examination revealed evidence of tubal involvement; this was usually chronic but sometimes acute.

\section{Results of treatment (Tables I and II)}

\section{Schedule 1}

300 women and 421 men. Failure occurred in nine women ( 3 per cent.) and seventeen men ( 4 per cent.).

\section{Schedule 2}

62 women. No failures.
TABLE I Results of treatment with two injections of 2 m.u. procaine penicillin

\begin{tabular}{|c|c|c|c|}
\hline \multirow[t]{2}{*}{ Sex } & \multirow[t]{2}{*}{ No. of cases } & \multicolumn{2}{|c|}{ Failures } \\
\hline & & No. & Per cent. \\
\hline $\begin{array}{l}\text { Male } \\
\text { Female }\end{array}$ & $\begin{array}{l}421 \\
300\end{array}$ & $\begin{array}{r}17 \\
9\end{array}$ & $\begin{array}{l}4.0 \\
3.0\end{array}$ \\
\hline Total & 721 & 26 & $3 \cdot 6$ \\
\hline
\end{tabular}

TABLE II Results of treatment in 512 female patients

\begin{tabular}{|c|c|c|c|}
\hline \multirow[t]{2}{*}{ Schedule } & \multirow[t]{2}{*}{ No. treated } & \multicolumn{2}{|c|}{ Failures } \\
\hline & & No. & Per cent. \\
\hline $\begin{array}{l}\text { (1) } 2 \times 2 \text { m.u. } \\
\text { procaine penicillin }\end{array}$ & 300 & 9 & 3 \\
\hline $\begin{array}{l}\text { (2) } 2 \times 4 \text { m.u. sodium } \\
\text { and procaine penicillin }\end{array}$ & 62 & 0 & 0 \\
\hline $\begin{array}{l}\text { (3) } 2 \text { g. cephaloridine } \\
\text { (4) } 2 \times 300 \mathrm{mg} \text {. } \\
\text { doxycycline }\end{array}$ & $\begin{array}{r}50 \\
100\end{array}$ & $\begin{array}{l}2 \\
0\end{array}$ & $\begin{array}{l}\mathbf{4} \\
0\end{array}$ \\
\hline
\end{tabular}

Schedule 3

50 women. Two ( 4 per cent.) failed to respond.

\section{Schedule 4}

100 women. No failures.

\section{Discussion}

The results of antibiotic therapy in gonorrhoea depend on the sensitivity of the organism to the antibiotic used and on the duration and concentration of the drug in the blood. In most cases the effect of adnexal involvement in women is overestimated. Penicillin is characterized by a particularly good penetration into inflamed tissue. Thus, in the stage of acute or sub-acute infection, a sufficiently high serum level will result in a high tissue level with consequent cure.

In chronic salpingitis, which is marked by inflamed granulation tissue with fibrosis and obliteration of the tubal lumen, the adnexae cannot be considered to be the cause of persistent infection in the cervix.

The mixed flora frequently present in women makes diagnosis difficult and this can often only be achieved by culture. False interpretation of smears can lead to a wrong diagnosis and thus to a so-called failure of penicillin treatment.

The 300 female patients admitted to hospital and treated with two injections of $2 \mathrm{~m}$.u. procaine penicillin responded well, as did the men who received the same treatment.

However, other bacterial flora present in the vaginal or urethral secretion may be an important factor in the outcome of therapy of gonorrhoea. In seven out of the nine women with gonococci still present after 
treatment with penicillin, organisms which might form penicillinase were isolated from the exudate. Mixed infections with such organisms may prove to be resistant to therapy even though the gonococci are sensitive to penicillin (Meyer-Rohn, 1964; Kokoschka, Söltz-Szöts, and Thurner, 1972).

Among the gonococcal strains isolated from the nine women who failed to respond to penicillin, five were sensitive to less than 0.5 i.u. penicillin $/ \mathrm{ml}$. and four to between 0.5 and 2 i.u. penicillin/ $\mathrm{ml}$. In three women there was evidence of adnexal involvement.

Even though the number of female patients treated with two injections of higher doses of a combined preparation ( 3.6 m.u. sodium penicillin $G+400,000$ i.u. procaine penicillin $G$ ) was small, the results may be regarded as optimal, and considerably better than those obtained with a single injection of this preparation (Petzoldt, 1971).

In patients with penicillin allergy, cephalosporins may not be a suitable alternative, since crossreactions have been observed (Walter and Heilmeyer, 1969). With a failure rate of only 4 per cent. after $2 \mathrm{~g}$. cephaloridine, this therapy is an otherwise excellent alternative treatment for gonorrhoea. With an increase in the dose to $3 \mathrm{~g}$. (in a single injection) we may expect these results to be even better-as indicated by a series of tests which are being carried out at present.

Because of the excellent results achieved with doxycycline, the brevity of the treatment $(8 \mathrm{hrs})$, and the good tolerance of this antibiotic, it seems to be indicated as an alternative treatment in cases of penicillin allergy.

In all forms of gonorrboea, penicillin is still the drug of choice. Numerous antibiotics developed during recent years are also satisfactory, but none has yet been able to replace penicillin. In addition to the dosage, the type of penicillin used is of great importance. Because of the relatively short generation cycle of the gonococcus (15 min.), a high penicillin level of short duration has proved to be more effective than one just above the sensitivity threshold of the organism (Krook and Juhlin, 1965; Willcox, 1968; Röckl, 1970; Luger, 1971 ; Söltz-Szöts and Kokoschka, in press). Having regard to the sensitivities of the strains of gonococci tested by us during recent years and the average serum levels obtainable with the most frequently used penicillin preparations, the best blood levels for the treatment of gonorrhoea are now being achieved by means of combined preparations which have been commercially available for the past few years. These contain 3.6 m.u. sodium penicillin $G$ and 400,000 i.u. of a depot drug such as procaine-penicillin $G$ or clemizol penicillin. In view of the unreliability of many patients with venereal disease, it is necessary, in the treatment of gonorrhoea, to keep the time required for treatment as short as possible and to obtain a cure with one or two injections. Thus schedules that extend over several days are now rarely used-particularly as they do not give better results.

Other chemotherapeutic agents may be used for the following reasons:

(1) Penicillin allergy.

(2) Failures due to inadequate penicillin sensitivity of the gonococcus.

(3) Mixed infections with organisms forming penicillinase.

(4) Antibiotics that have proved superior when given in a single dose.

\section{Summary}

From January, 1971, to May, 1972, gonorrhoea was diagnosed and confirmed by culture in 512 female patients; 410 of these women were admitted to hospital for treatment and 102 received out-patient treatment. There were nine failures ( 3 per cent.) among 300 women given two injections of $2 \mathrm{~m} . \mathrm{u}$. procaine penicillin, none among 62 women given two injections of 3.6 m.u. sodium penicillin plus 400,000 i.u. procaine penicillin $G$, two ( 4 per cent.) among fifty women given a single injection of $2 \mathrm{~g}$. cephaloridine, and none among a hundred women given two oral doses of $300 \mathrm{mg}$. doxycycline.

The results are compared with those obtained by treating 421 men suffering from uncomplicated gonorrhoea with the first schedule (4 per cent. failures).

The sensitivities of the strains of gonococcus ranged from 0.0039 to $2 \mathrm{~m} . \mathrm{u}$. penicillin per ml. serum.

Therapeutic failures in women could not always be ascribed to reduced penicillin sensitivity of the gonococcus and seemed to be unrelated to adnexal involvement. In some cases treatment failure may have been due to mixed infections with bacteria forming penicillinase.

\section{References}

Kokoschka, E. M., SöLtz-Szöts, J., and ThURNER, J. (1972) Z. Haut u. Geschl.-Kr., 47, 423

Krook, G., and Juhlin, I. (1965) Acta derm.-venereol. (Stockh.), 45, 242

Luger, A. (1971) Med. Klin., 66, 339

MEYeR-Rohn, J. (1964) Dtsch. med. Wschr., 89, 2197

Petzoldt, D. (1971) Hautarzt, 22, 523

RöckL, H. (1970) In 'Fortschritte der praktischen Dermatologie und Venereologie', ed. O. Braun-Falco and H. J. Bandmann, vol. 6, pp. 59-64. Springer, Berlin, Heidelberg, New York 
Söltz-Szöts, J., and KokoschKA, E. M. (in press) 'Diagnose und Therapie der Geschlechtskrankheiten'. Maudrich, Vienna

WALTER, A. M., and HeIlMEYeR, L. (1969) 'AntibiotikaFibel', p. 222. Thieme, Stuttgart

WERNER, H.-P., KRAFT, D., STEMBERGER, H., and WIEDERMANN, G. (1972) Hautarzt, 23, 207

Willcox, R. R. (1968) 'Antibiotic Treatment of Venereal Diseases'. Curr. Probl. Derm., ed. A. Luger, vol. 2, p. 101-140. Karger, Basel

\section{Traitement de la gonococcie avec pénicilline, céphaloridine et doxycycline}

\section{SOMMAIRE}

De Janvier 1971 à Mai 1972 la gonococcie fut reconnue et confirmée par culture chez 512 femmes. 410 d'entre elles furent hospitalisées pour traitement et 102 eurent un traitement ambulatoire. Il y eut 9 échecs ( 3 pour cent) chez les 300 femmes ayant reçu deux injections de 2 m.u. de pénicilline procaine, aucun parmi les 62 femmes ayant reçu deux injections de $3,6 \mathrm{~m} . \mathrm{u}$ de pénicilline sodique plus 4.000 unités internationales de procaine pénicilline $G$, il y en eut 2 (4 pour cent) parmi les 50 femmes ayant reçu une injection unique de $2 \mathrm{~g}$. de céphaloridine et 9 sur 100 femmes qui reçurent une dose orale de doxycycline.

On a comparé les résultats avec ceux obtenus chez 421 hommes atteints de gonococcie non compliquée et traités selon le premier schema.

Les sensibilités des souches de gonocoques allèrent de 0,0039 à $2 \mathrm{~m}$.u. de pénicilline par ml. de sérum.

Les échecs thérapeutiques chez les femmes ne peuvent pas toujours être attribués à une sensibilité réduite du gonocoque à la pénicilline et semblent sans relation avec une atteinte annexielle. Dans quelques cas, l'echec peut avoir été dû à une infection mixte par des bactéries secrétant de la pénicillinase. 